\title{
Pemberdayaan masyarakat di Desa Balai Makam dalam pemanfaatan bonggol pisang sebagai rintisan Usaha Mikro Kecil Menengah (UMKM)
}

\author{
Tetty Marta Linda*, Sezhianindi Firiola, Rahmah Agnissah, Binar Robinson M, Muhammad \\ Rinaldi, \& Sri Ramadhani
}

Fakultas Matematika dan Ilmu Pengetahuan Alam, Universitas Riau

* tetty.martalinda@lecturer.unri.ac.id

\begin{abstract}
Abstrak. Bonggol pisang salah satu bagian tanaman pisang yang masih sangat jarang dimanfaatkan. Bonggol pisang dapat menjadi barang yang memiliki nilai jual karena mengandung karbohidrat, serat dan kalsium yang tinggi sehingga dapat menjadi bahan pangan alternatif.. Bonggol pisang dapat diubah menjadi tepung yang kaya gizi. Pemberdayaan masyarakat untuk mengolah bonggol pisang menjadi sesuatu yang berguna dan dapat menjadi rintisan usaha bagi warga salah satu kunci keberhasilan kegiatan ini. Pengabdian ini akan memberikan manfaat kepada berbagai pihak, diantaranya bagi peserta pengabdian bagi masyarakat, bagi tim pelaksana penyuluhan, bagi Perguruan Tinggi dan bagi pemerintah. Tujuan kegiatan ini adalah mengenalkan dan melatih keterampilan pembuatan tepung yang berbahan dari bonggol pisang yang kami beri nama "Tebosang" bagi masyarakat Desa Balai Makam Kecamatan Bathin Solapan Kabupaten Bengkalis. Metode yang digunakan meliputi survei lokasi, persiapan pelatihan interaktif, pendampingan, monitoring dan evaluasi. Pembuatan tepung dari bonggol pisang adalah limbah bonggol pisang tua dibersihkan permukaannya, selanjutnya diiris tipis kira-kira $0.5 \mathrm{~cm}$. Bonggol yang telah diiris tipis dilakukan pencucian selanjutnya di rendam dengan kapur sirih selama kurang lebih satu jam lalu dibilas dan dikeringkan. Irisan bonggol yang telah kering selanjutnya di blender lalu di ayak sehingga menjadi tepung. Antusias masyarakat cukup besar pada saat pelatihan yang ditunjukkan dengan keterlibatan masyarakat saat demonstrasi. Hasil monitoring dan evaluasi menunjukkan masyarakat sudah paham tentang cara pembuatan tepung dari bonggol pisang dan juga diketahui bahwa masyarakat desa sudah ada yang memproduksi tepung "tebosang" yang memiliki potensi komersial yang dapat dijadikan sebagai rintisan usaha mikro, kecil dan menengah di setiap warga.
\end{abstract}

Kata kunci: Bonggol pisang, ketrampilan, pangan alternatif, serat

\begin{abstract}
Banana hump is one part of the banana plant that is still very rarely used. The Banana hump can be an item with a selling value because it contains high carbohydrates, fiber, and calcium to be an alternative food ingredient. The banana hump can be turned into nutrient-rich flour. Community empowerment to process banana hump into something useful and can be a pilot business for residents is one of the keys to this success of this activity. This service will provide benefits to various parties, including for community service participants, for the counseling implementation team, for universities, and for the government. The purpose of this activity is to introduce and train the skills of making flour made from banana humps, which we named "Tebosang" for the community of Balai Makam Village, Bathin Solapan District, Bengkalis Regency. The methods used include site surveys, interactive training preparation, mentoring, monitoring, and evaluation. Making flour from banana hump started with a waste of old banana hump, cleaned the surface, then sliced thin approximately $0.5 \mathrm{~cm}$. The hump then washed and then soaked with whiting for about one hour, then rinsed and dried. The dried hump slices are then blended and then sifted so that they become flour. The community's enthusiasm was relatively high at the time of the training, shown by the community's involvement at the demonstration. The monitoring and evaluation results show that the community already understands how to make flour from the banana hump. The result also showed that the village community is already producing "tebosang" flour, which has commercial potential, a start-up for micro, small and medium enterprises in each community.
\end{abstract}

Keywords: Banana hump, soft skill, food ingredient, fiber

To cite this article: Linda, T. M., S. Firiola., R. Agnissah., B. Robinson, M., M. Rinaldi., \& S. Ramadhani. 2020.

Pemberdayaan masyarakat di Desa Balai Makam dalam pemanfaatan bonggol pisang sebagai rintisan Usaha Mikro

Kecil Menengah (UMKM). Unri Conference Series: Community Engagement 2: 344-351

https://doi.org/10.31258/unricsce.2.344-351

(C) 2020 Authors

Peer-review under responsibility of the organizing committee of Seminar Nasional Pemberdayaan Masyarakat 2020 


\section{PENDAHULUAN}

Kabupaten Bengkalis merupakan salah satu kabupaten dengan hasil hortikultura tertinggi buah pisang yaitu mencapai 15649 kwintal (BPS Kabupaten Bengkalis 2017). Salah satu sentra penghasilnya adalah Desa Balai Makam Kecamatan Bathin Solapan. Kecamatan ini memiliki luas wilayah 45,00 km2 dengan jumlah penduduk 85971 yang terdiri dari 44519 laki-laki dan 41452 perempuan. Penduduk Desa Balai Makam dengan mata pencaharian kerja di perusahaan sebagai buruh dan bertani. Tanaman pangan yang ditanam di desa ini adalah padi sawah dan padi ladang (BPS Kabupaten Bengkalis 2019) selain itu banyak dijumpai warga menanam tanaman pisang dengan berbagai jenis terutama pisang kepok. Hasil panen pisang ini menurut warga dapat menambah pendapatan. Hampir setiap rumah memiliki ladang pisang. Tanaman pisang terdiri atas daun, batang, buah, jantung, dan bonggol yang memiliki manfaatnya masing-masing. Diantara sekian banyak bagian dari tanaman pisang, bonggol pisang adalah salah satu bagian yang sangat jarang digunakan oleh masyarakat.

Fenomena belum dimanfaatkannya bonggol pisang di Desa Balai Makam menarik minat kami selaku tim untuk melakukan pengabdian masyarakat agar bonggol pisang kepok dapat dimanfaatkan dan memberikan manfaat untuk meningkatkan ekonomi keluarga. Desa Balai Makam merupakan sebuah desa di Kecamatan Bathin Solapan, Kabupaten Bengkalis, Riau yang terletak pada 1015’34.568 LU, 101o12'47.211 BT dengan jarak tempuh ke desa berkisar $140 \mathrm{~km}$ dari kota Pekanbaru. Kondisi ekonomi masyarakat masih tergolong menengah kebawah. Informasi nonformal yang kami peroleh terjadi peningkatan pengangguran di desa ini pada tahun 2018 yang disebabkan oleh penutupan lapangan pekerjaan oleh beberapa perusahaan kecil hingga besar. Hal ini berdampak pada kesejahteraan masyarakat desa.

Desa Balai Makam yang memiliki potensi untuk meningkatkan ekonomi masyarakat tetapi belum tersentuh untuk dilakukan pemberdayaan sumber alam yang berupa tanaman pisang. Selama ini masyarakat hanya menjual buah pisang dan daunnya saja, sedangkan manfaat tanaman pisang lainnya khusus bonggol belum pernah. Memanfaatkan limbah bonggol pisang bukanlah hal yang terpikirkan oleh masyarakat Desa Balai Makam, sehingga hal ini perlu di edukasikan kepada masyarakat desa agar munculnya minat dan tersedianya peluang usaha yang baru untuk dapat meningkatkan perekonomian mereka.

Bahan limbah jika dimanfaatkan dengan baik mempunyai potensi komersial yang dapat mendorong kemampuan wirausaha dan pertumbuhan ekonomi masyarakat tempatan. Selama ini bonggol pisang hanya dijadikan pakan ternak atau limbah, namun kenyataannya, bonggol pisang sangat aman untuk dimanfaatkan dan dikonsumsi. Menurut Saragih (2013), tepung bonggol pisang yang terbaik dari varietas pisang kepok setelah dipanen memiliki karakteristik adalah kadar air 1,02\%, kadar abu 0,8\%, rendemen 10,42\%, daya kembang 0,37\% serap air 254,3\%, serat kasar 29,2\%, pati resisten sebesar 39,35\% kandungan prebiotik Fruktooligosakarida (FOS) sebanyak 427,03 mg/mL (Musita 2012). Hasil penelitian Sembiring (2017) kandungan gizi tepung bonggol pisang kepok yaitu karbohidrat: 79,16\%, lemak: 2,15\%, protein: 3,58\%. Bonggol pisang sudah banyak dimanfaatkan diantaranya sebagai bahan plastik biodegradable (Nafiyanto, 2019), makanan ringan kripik (Mavianti 2019), penghasil zat warna (Putra 2014), tepung untuk choco cookies (Saputra, et al. 2019) dan tepung untuk campuran cookies (Ginting, 2019).

Tepung bonggol pisang kepok kualitas terbaik untuk dijadikan tepung dengan kadar air lebih rendah, kemampuan daya serap air yang tinggi dan serat kasar dan prebiotik tinggi mampu menekan produksi glukosa. Hal ini dapat mencegah berbagai macam penyakit diantaranya diabetes mellitus. Menurut Markowiak dan Ślizewska 2017 kefir tepung pisang kepok merupakan sinbiotik yang dapat berfungsi dalam metabolisme glukosa dan sensitivitas pada hiperglikemia.

Tujuan kegiatan ini adalah memberikan pengetahuan dan keterampilan kepada warga masyarakat di Desa Balai Makam untuk mengolah bonggol pisang menjadi tepung. Produk berupa tepung ini dapat sebagai rintisan usaha Mikro Kecil Menengah (UMKM) bagi warga desa agar dapat memiliki kemandirian dan meningkatkan kesejahteraan keluarga.

\section{METODE PENERAPAN}

Metode yang digunakan dalam kegiatan ini yaitu sosialisasi dengan metode ceramah, pendampingan dengan praktek langsung serta dilakukan pemantauan dengan evaluasi capaian kegiatan. dengan menggunakan alat ukur ketercapaian.

\section{Tahap pertama: Sosialisasi Edukasi Tebosang}

Sosialisasi dilaksanakan dengan menjelaskan pengetahuan seputar bonggol pisang, jenis-jenis pisang, kandungan nutrisinya, dan manfaat dari segi ekonomi dan kesehatan. Mendemonstrasikan tahap-tahap 
pembuatan tepung bonggol pisang. Menyebarkan kuesioner untuk mengetahui sejauh mana pengetahuan warga tentang pemanfaatan bonggol pisang. Tujuan sosialisasi ini adalah untuk memberikan bekal ilmu pengetahuan atau informasi kepada masyarakat tentang bonggol pisang yang sebagai limbah dapat dimanfaatkan untuk bahan tepung yang bergizi.

\section{Tahap kedua: Pendampingan}

Melakukan pengawasan kepada masyarakat terhadap perkembangan program yang dijalankan. Penggunaan metode ceramah dikombinasikan dengan memanfaatkan laptop dan LCD untuk menayangkan materi PowerPoint yang dilengkapi dengan gambar-gambar. Masyarakat juga diberikan beberapa resep yang dapat digunakan untuk penggunaan produk "Tebosang" menjadi sebuah kue ataupun cookies.

Cara membuat tepung dari bonggol pisang yang diberi nama Tebosang adalah:

1. Pemilihan bonggol pisang

Bonggol pisang yang digunakan harus dalam keadaan segar, yaitu setelah pohon pisang ditebang, Hal ini untuk mendapatkan hasil akhir tepung yang bagus. Jika bonggol pisang dibiarkan terlalu lama akan merubah warna dan tekstur serta ketahanan tepung.

2. Pembersihan bonggol pisang

Bonggol pisang melalui tahapan pembersihan, bagian luar bonggol pisang yang lebih keras di potong dan sisakan bagian tengah atau seringkali disebut sebagai hati bonggol.

3. Pemotongan bonggol pisang

Bagian pemotongan dan penipisan bonggol pisang ini mempengaruhi proses pengeringan pada bonggol pisang, bonggol pisang harus diiris tipis dengan bantuan pisau pengiris. Ukuran irisan yang digunakan $\pm 0,5$ $\mathrm{cm}$, semakin tipis irisan maka pengeringan akan membutuhkan waktu yang semakin cepat, selain itu proses penghalusan dari bonggol kering menjadi tepung bonggol pisang akan lebih mudah.

4. Perendaman

Perendaman bonggol pisang dilakukan untuk menghilangkan getah dan rasa sepat pada bonggol. Tahapan menghilangkan getah dan rasa sepat adalah:

a. Perendaman dilakukan dengan penambahan kapur sirih pada air rendaman. Pemberian kapur sirih tergantung dengan jumlah bonggol pisang dan air rendaman, 1 sendok makan kapur sirih digunakan untuk air rendaman sebanyak \pm 5 Liter yang merendam 1 bonggol berukuran $10 \mathrm{~kg}$.

b. Proses perendaman dilakukan selama 8 jam agar getah yang menempel mulai terpisah dari bonggol pisang dan selanjutnya dapat dibersihkan dengan cara mengucek rendaman bonggol tersebut agar getah yang melekat terpisah dari bonggol, getah ini dapat berupa serabut-serabut, selanjutnya bonggol pisang ditiriskan untuk persiapan penjemuran. Selain menghilangkan rasa sepat pada bonggol pisang, melalui perendaman ini didapatkan juga tekstur bonggol yang baik dan tidak berbau.

5. Pengeringan irisan bonggol

Pengeringan bonggol pisang dilakukan dengan bantuan sinar matahari, namun untuk menjaga kandungan gizi dari bonggol pisang, maka pengeringan tidak boleh langsung dibawah sinar matahari.

6. Proses penghalusan bonggol kering untuk menjadi tepung secara sederhana dapat menggunakan blender. Hasil tepung kemudian diayak untuk memisahkan sisa getah kering pada bonggol kering. Dalam skala besar pembuatan tepung bonggol pisang dapat menggunakan mesin penggiling tepung, Penggunaan mesin penggiling tepung juga akan menghasilkan tepung bonggol pisang yang lebih halus. Kegiatan penghalusan bonggol pisang kering menghasilkan debu dari tepung bonggol tersebut, sebaiknya pengerjaannya menggunakan masker.

\section{Tahap ketiga: Pemantauan}

Pemantauan bertujuan untuk melihat perkembangan dari masyarakat terhadap kemajuan pembuatan produk oleh masyarakat itu sendiri. Pada kegiatan ini, tim melihat hasil produksi tepung yang telah dibuat oleh warga.

\section{HASIL DAN KETERCAPAIAN SASARAN}

Kegiatan pengabdian ini dimulai dengan orientasi lapangan dalam penetapan Desa Balai Makam sebagai lokasi kegiatan dengan meninjau potensi yang dimiliki masyarakat serta kesesuaian kebutuhan masyarakat. Pada orientasi lapangan, tim pelaksana bertemu dengan tokoh masyarakat desa serta beberapa masyarakat. Masyarakat menyambut tim dengan baik dan sangat mendukung kegiatan yang akan dilaksanakan karena para masyarakat melihat potensi yang dimiliki kegiatan ini, terutama para ibu-ibu dan petani yang ada di Desa Balai Makam. 
Hampir seluruh warga Desa Balai Makam memiliki pohon pisang baik berupa kebun ataupun tanaman di halaman rumah. Bertani bukanlah mata pencaharian utama masyarakat setempat, umumnya warga Desa Balai Makam bekerja sebagai buruh pabrik atau buruh harian lepas. Berdasarkan hasil survey pada kegiatan sosialisasi, hampir seluruh masyarakat belum mengetahui bahwa bonggol pisang mampu dijadikan sebagai pengganti bahan dasar pembuatan tepung layaknya bahan yang umumnya digunakan dalam pembuatan tepung konvensional.
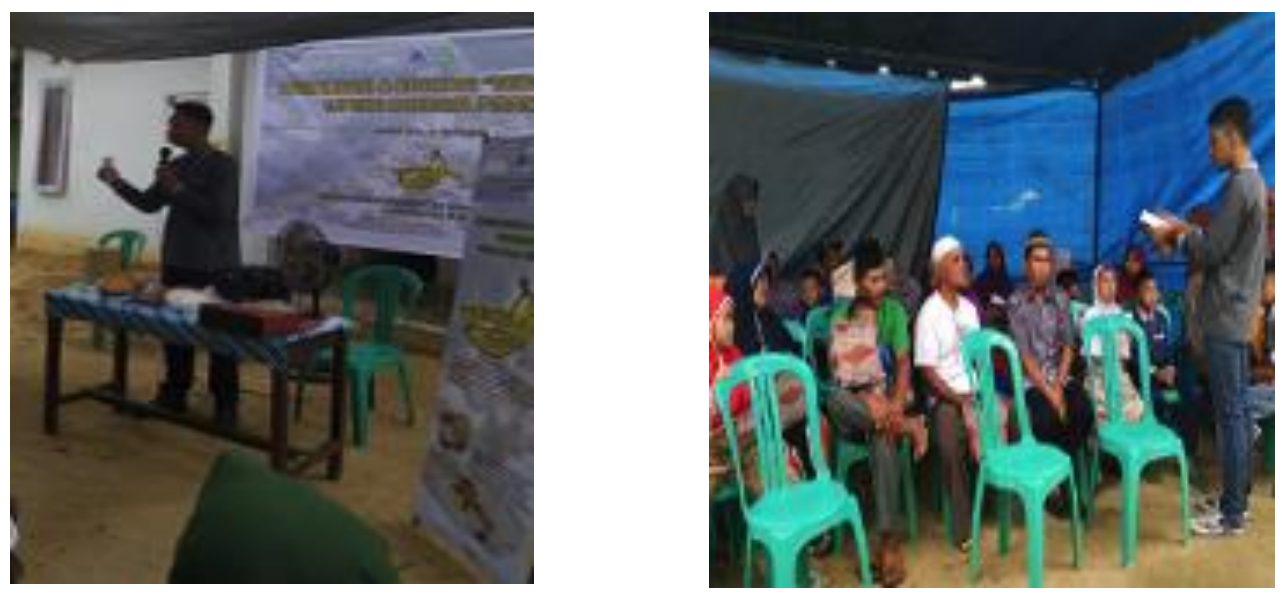

Gambar 1. Sosialisasi pengolahan tepung dari bonggol pisang

Materi edukasi tim pengabdian adalah memberikan pengetahuan pengolahan bonggol pisang menjadi tepung dengan nama produk "Tebosang" (tepung bonggol pisang). Langkah-langkahnya adalah: Pengambilan bonggol pisang. Bonggol pisang merupakan bagian yang terletak di pangkal batang, berbentuk bulat dan besar. Bonggol terdiri atas batang asli yang disebut bonggol (corn) dan batang palsu atau batang semu. Bonggol (corm) terletak dibawah permukaan tanah dan mempunyai beberapa mata (pink eye) yang tersusun dari pelepah daun yang saling menutupi, tumbuh tegak dan kokoh diatas permukaan tanah. Pada tahap ini juga diberikan edukasi secara langsung kepada warga mengenai langkah-langkah pemilihan bonggol pisang dan cara pengolahannya sehingga menjadi tepung (Gambar 1).

Sebelum sosialisasi dilakukan sebanyak $81 \%$ dari peserta yang hadir, tidak mengetahui manfaat dari bonggol pisang. Kegiatan sosialisasi ini merupakan salah satu solusi yang tepat bagi masyarakat Desa Balai Makam guna menambah pengetahuan masyarakat terhadap besarnya manfaat bonggol pisang. Setelah dilakukannya kegiatan sosialisasi dan edukasi tebosang, sebanyak 94\% dari masyarakat yang hadir telah mengetahui manfaat dari bonggol pisang. Hal ini menunjukkan adanya peningkatan pemahaman peserta terhadap potensi yang dimiliki oleh bonggol pisang. Besarnya manfaat dari bonggol pisang menunjukkan bahwa bonggol pisang memang dapat dijadikan bahan pangan alternatif, sehingga nantinya dapat membantu pendapatan masyarakat Desa Balai Makam.

Kegiatan ini telah memberikan dampak yaitu masyarakat tertarik terhadap bonggol pisang yang selama ini tidak pernah diolah. Diketahui dari kuesioner sebanyak 32 peserta yang hadir, seluruhnya memiliki antusias dan keingintahuan yang tinggi terhadap bonggol pisang. Para peserta yakin bahwa bonggol pisang memiliki peluang yang besar untuk dikembangkan dan dijadikan sumber ekonomi tambahan.

Masyarakat juga diberi informasi kualitas bonggol pisang yang baik adalah bonggol pisang yang diambil bersamaan dengan penebangan pohon pisang. Kualitas bonggol akan menurun setelah tiga hari pohon pisang ditebang, bonggol mengalami perubahan warna akibat pengaruh sistem respirasi pada umbi tersebut. Respirasi tersebut menyebabkan berkurangnya cadangan makanan (dalam bentuk pati, gula, dan lain-lain) dalam komoditas, mengurangi rasa dari komoditas (terasa hambar) dan memacu pembusukkan. Pengolahan awal bonggol pisang seperti pada Gambar 2. 


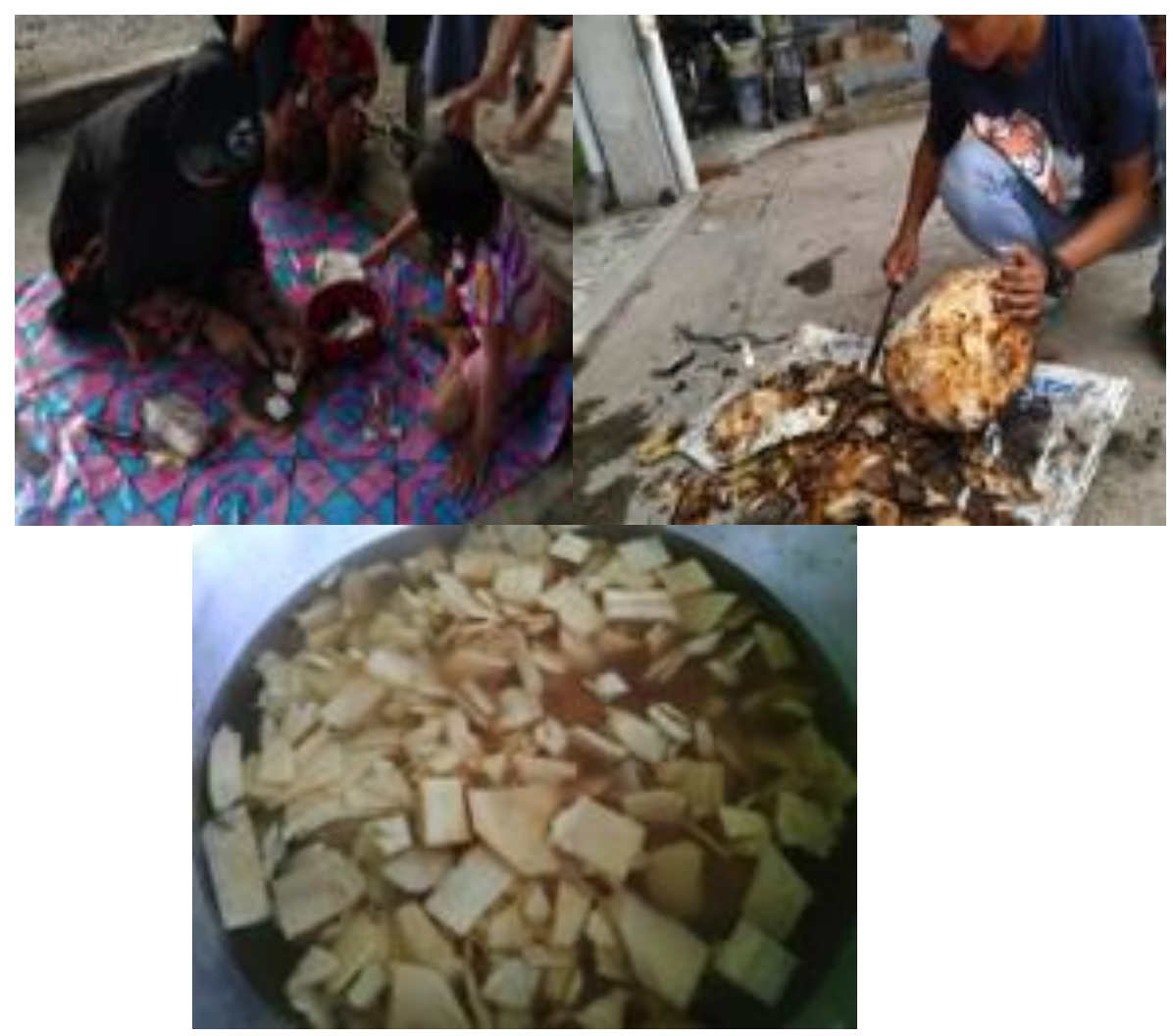

Gambar 2. Pengolahan awal bonggol pisang kepok sebelum dibuat tepung

Pada kegiatan pendampingan dan memantau kembali program yang dilaksanakan di lokasi pengabdian sudah terdapat tiga keluarga yang telah melakukan percobaan dalam pembuatan tepung bonggol pisang. Tujuan pendampingan ini adalah agar tim mengetahui kendala serta hambatan yang dimiliki masyarakat dalam pembuatan produk tepung bonggol pisang. Pemantauan untuk mengetahui seberapa jauh pengetahuan masyarakat mengenai bonggol pisang, tim mengumpulkan data dari kuesioner yang telah dibagikan sebelum kegiatan sosialisasi.

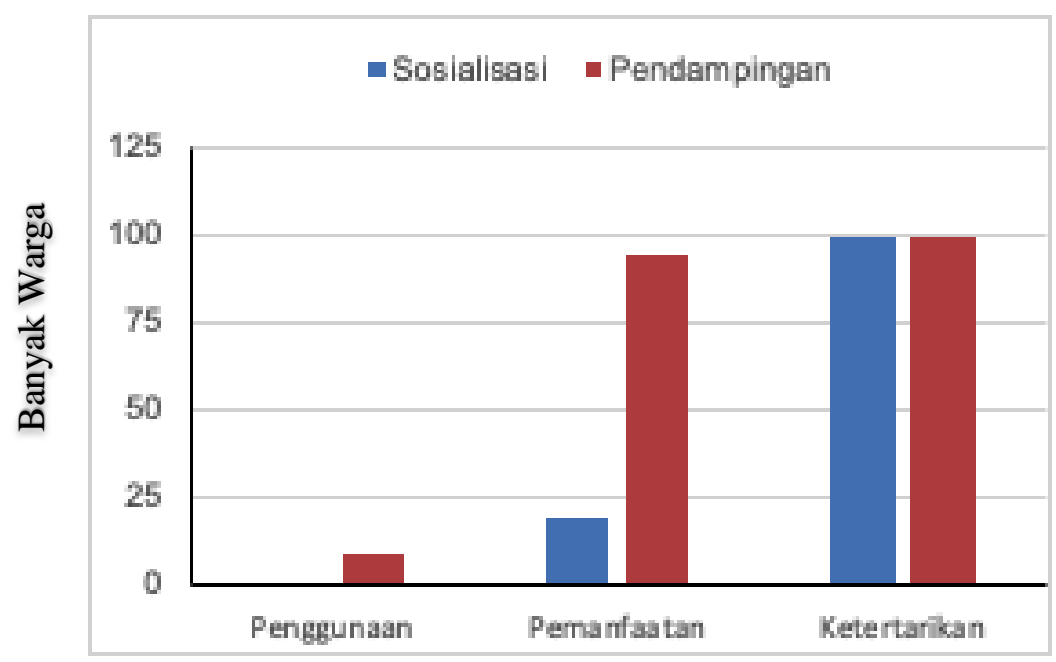

Gambar 3. Hasil evaluasi kuesioner saat kegiatan sosialisasi dan evaluasi

Hasil quisioner, dari 32 peserta yang hadir, 100\% masyarakat desa balai makam belum pernah memanfaatkan bonggol pisang. Peningkatan terjadi ketika tim melakukan pendampingan, bahwa sebanyak 3 keluarga telah mencoba memproduksi bonggol pisang. Kurangnya pengetahuan masyarakat terhadap manfaat 
dan keunggulan bonggol pisang membuat bagian ini sangat jarang dimanfaatkan, padahal bonggol pisang memiliki kandungan yang sangat baik untuk kesehatan. melancarkan pencernaan. Hasil nugget bonggol pisang yang telah dibuat dilakukan pengujian menggunakan metode SNI 01-3553-3006. Menurut Rakhmawati (2019), Nugget bonggol pisang mempunyai khasiat dalam melancarkan pencernaan. Hasil nugget bonggol pisang yang telah dibuat dilakukan pengujian menggunakan metode SNI 01-3553-3006. Setiap 1 Gram nugget bonggol pisang mengandung 50,29\% kadar air, 6,19\% kadar abu, dan 23,63\% serat kasar. Nugget bonggol pisang ini mengandung zat-zat bermanfaat yang diperlukan oleh tubuh. Kandungan gizinya yang lengkap seperti tannin, saponin, flavonoid, serotonin, neropinefrin, hidroksitriptamin, dopamine, vitamin A, vitamin B, vitamin $C$ dan serat bisa berfungsi sebagai obat, meningkatkan kekelah tubuh, dan sebagai antiseptic.

Gambar 3. menunjukkan hasil kuesioner. Jumlah peserta peserta yang hadir 32 orang, 100\% masyarakat Desa Balai Makam belum pernah memanfaatkan bonggol pisang. Peningkatan terjadi ketika tim melakukan pendampingan, bahwa sudah ada beberapa keluarga telah mencoba memproduksi tepung bonggol pisang. Kurangnya pengetahuan masyarakat terhadap manfaat dan keunggulan bonggol pisang membuat bagian ini sangat jarang dimanfaatkan, padahal bonggol pisang memiliki kandungan yang sangat baik untuk kesehatan, melancarkan pencernaan. Menurut Rakhmawati (2019), nugget bonggol pisang mempunyai khasiat dalam melancarkan pencernaan. Evaluasi nugget bonggol pisang yang telah dilakukan pengujian dengan SNI 013553-3006. Setiap 1 Gram nugget bonggol pisang mengandung 50,29\% kadar air, 6,19\% kadar abu, dan $23,63 \%$ serat kasar. Nugget bonggol pisang ini mengandung zat-zat bermanfaat yang diperlukan oleh tubuh. Kandungan gizinya yang lengkap seperti tanin, saponin, flavonoid, serotonin, norepinefrin, hidroksitriptamin, dopamine, vitamin A, vitamin B, vitamin C dan serat bisa berfungsi sebagai obat, meningkatkan kekelah tubuh, dan sebagai antiseptik.

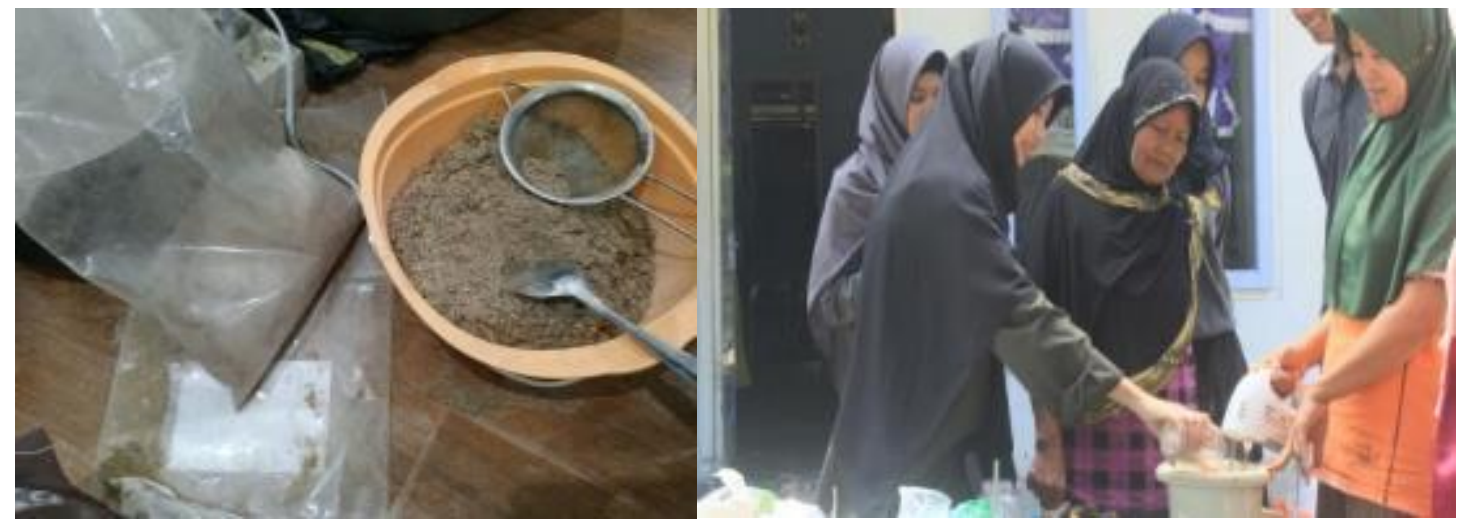

Gambar 4. Hasil pengolahan bonggol pisang menjadi tepung dan pemanfaatannya sebagai bahan makanan

Dampak lain setelah kegiatan sosialisasi dan edukasi tebosang, pihak desa melakukan pembentukan kelompok guna melanjutkan perkembangan dari produksi tepung bonggol pisang. Gambar 4 adalah hasil pengolahan bonggol pisang yang selanjutnya dapat dimanfaatkan sebagai bahan makanan yang didampingi oleh tim. Penggunaan produk bonggol pisang menjadi olahan tepung sudah mendapat dukungan ilmiah yang berisikan kadar serta manfaat dari bonggol pisang. Beberapa peneliti sudah menggunakan bonggol pisang sebagai bahan pangan alternatif yang dapat diolah menjadi kue ataupun jenis makanan lainnya. Untuk memudahkan masyarakat dalam keberlanjutan pembuatan tepung dan pengembangannya kami membuatkan buku teknologi tepat guna (TTG) dengan ISBN 978-979-792-927-5 yang berisikan cara pembuatan dan beberapa resep olahan dari tepung bonggol pisang dengan cover seperti Gambar 4. 


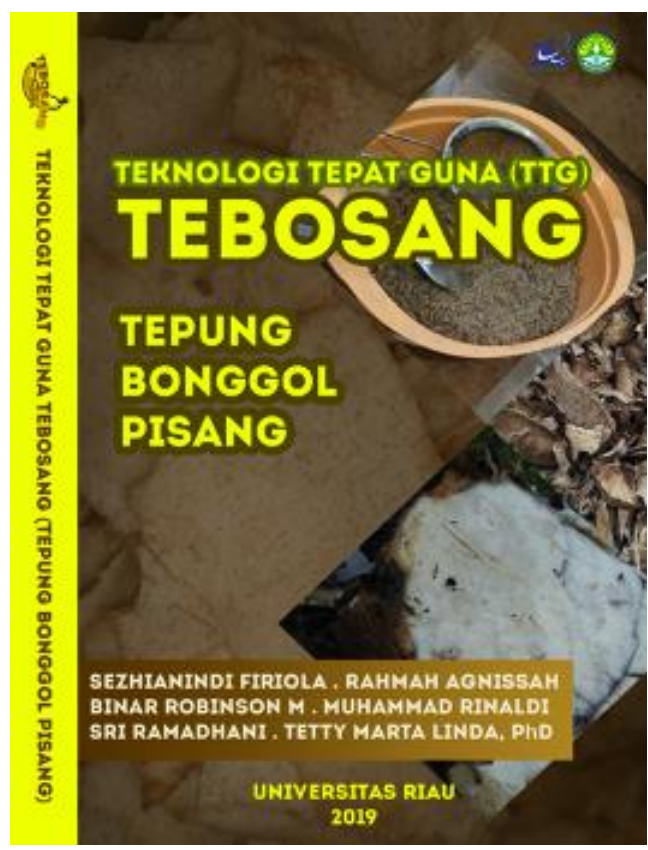

Gambar 5. Buku Teknologi Tepat Guna (TTG) Tebosang ISBN 978-979-792-927-5

\section{KESIMPULAN}

Kegiatan pemberdayaan masyarakat di Desa Balai Makam dalam pemanfaatan bonggol pisang sebagai rintisan usaha mikro kecil menengah (UMKM) berjalan dengan baik dan lancar serta bermanfaat bagi peserta. Hasil kuesioner $81 \%$ peserta belum mengetahui manfaat dari bonggol pisang dan $100 \%$ peserta antusias dan berminat mempraktekkan. Pelatihan pembuatan tepung bonggol pisang diikuti oleh peserta yang antusias mengikuti semua rangkaian proses pengolahan dari bonggol menjadi potongan yang siap dikeringkan untuk selanjutnya dapat dijadikan tepung. Saat evaluasi sudah ada masyarakat yang mempraktekkan sendiri dan memproduksi tepung tebosang.

\section{UCAPAN TERIMA KASIH}

Terimakasih kepada KEMENRISTEK DIKTI yang telah mendanai kegiatan ini melalui Program Kreatif Mahasiswa-Pengabdian Kepada Masyarakat (PKM-M) tahun anggaran 2019. Kami juga mengucapkan terimakasih pada Bapak Kepala desa dan warga desa Balai Makam sehingga kegiatan ini dapat terlaksana dengan baik.

\section{DAFTAR PUSTAKA}

Badan Pusat Statistik. 2019. Kecamatan Bathin Solapan Dalam Angka 2019. BPS Kabupaten Bengkalis.

Badan Pusat Statistik. 2017. Produksi Tanaman Hortikultura. https://bengkaliskab.bps.go.id/statictable/2017/02/26/22/produksi-tanaman-hortikultura-buah-buahan-kabupatenbengkalis-tahun-2015-kuintal-.htm. Badan Pusat Statistik Kabupaten Bengkalis.

Markowiak, P dan Ślizewska, K. 2017. Effects of Probiotics, Prebiotics, and Synbiotics on Human Health. Nutrients, 9 , 1021. https://doi.org/10.3390/nu9091021

Mavianti dan R. N. Rizky. 2019. Upaya Pemanfaatan Bonggol Pisang Dalam Meningkatkan Ekonomi Keluarga Pada Ibu-Ibu Di Dusun 2 Desa Tanjung Anom. Prosiding Seminar Nasional Kewirausahaan, 1(1), 138-143. https://doi.org/10.30596/snk.v1i1.3591

Nafiyanto, I. 2019. Pembuatan Plastik Biodegradable Dari Limbah Bonggol Pisang Kepok dengan Plasticizer Gliserol Dari Minyak Jelantah dan Komposit Kitosan Dari Limbah Cangkang Bekicot (Achatina Fullica). Integrated Lab Journal, 7(1), 75-89. https://doi.org/10.5281/zenodo.2656812

Putra, A. A. B., N. W. Bogoriani, N. P. Diantariani, dan N. L. U. Sumadewi. 2014. Ekstraksi Zat Warna Alam dari Bonggol Tanaman Pisang (Musa paradiasciaca L.) Dengan Metode Maserasi, Refluks, dan Sokletasi. Jurnal Kimia, 8(1), 113-119. 
Rakhmawati. 2019. Pemanfaatan Bonggol Pisang Menjadi Stick Nugget untuk Peningkatan Gizi Masyarakat Desa Soket Laok Tragah Kabupaten Bangkalan. Jurnal Ilmiah Pengabdi. 5(1), 44

Saputra, M. W. L., R. P. Ariani., dan Damiati. 2019. Pemanfaatan Tepung Bonggol Pisang Kepok (Musa Acuminata Balbisiana) Menjadi Choco Cookies. Jurnal Bosaparis: Pendidikan Kesejahteraan Keluarga, 10(3), $195-204$.

Saragih B. 2013. Analisis Mutu Tepung Bonggol Pisang Dari Berbagai Varietas Dan Umur Panen Yang Berbeda. Jurnal Teknologi Industri Baga dan Busana, 9(1), 22-29.

Sembiring, S. 2017. Penggunaan Tepung Bonggol Pisang Kepok Hasil Fermentasi Dengan Saccharomyces cerevisiae dan Aspergillus niger Sebagai Pakan Dan Implikasinya Terhadap Kecernaan Nutrien Dan Performa Ternak Babi Fase Grower" Universitas Brawijaya. Http://repository.ub.ac.id/953

Septiana R. 2013. Pengaruh Substitusi Tepung Bonggol Pisang Ambon (Musa paradisiaca) Terhadap Tingkat Kekerasan Daya Terima Cookies. Karya Tulis Ilmiah.Fakultas Ilmu Kesehatan. Universitas Muhammadiyah Surakarta. 